Article

\title{
Assessment of COVID-19 Fear in Five European Countries before Mass Vaccination and Key Predictors among Nurses and Nursing Students
}

\author{
Evridiki Patelarou ${ }^{1, *}$, Petros Galanis ${ }^{2}$ D, Enkeleint A. Mechili ${ }^{3,4}{ }^{\mathbb{D}}$, Agathi Argyriadi ${ }^{5}$, \\ Alexandros Argyriadis ${ }^{6}$ (D), Evanthia Asimakopoulou ${ }^{6}$, Emirjona Kicaj ${ }^{4}$, Jorgjia Bucaj ${ }^{4}$, \\ Juan Manuel Carmona-Torres ${ }^{7}$ (D), Ana Isabel Cobo-Cuenca ${ }^{7}$ (D), Jakub Doležel ${ }^{8}$ (D), \\ Stefano Finotto ${ }^{9,10}\left(\mathbb{D}\right.$, Darja Jarošová ${ }^{8}\left(\mathbb{D}\right.$, Athina Kalokairinou ${ }^{2}$, Daniela Mecugni $9{ }^{9}$, \\ Velide Pulomenaj ${ }^{11}$ (D), Krenar Malaj ${ }^{12}$, Idriz Sopjani ${ }^{11}$, Majlinda Zahaj ${ }^{4}$ and Athina Patelarou ${ }^{1}$ (D)
}

check for updates

Citation: Patelarou, E.; Galanis, P.; Mechili, E.A.; Argyriadi, A.; Argyriadis, A.; Asimakopoulou, E.; Kicaj, E.; Bucaj, J.; Carmona-Torres, J.M.; Cobo-Cuenca, A.I.; et al. Assessment of COVID-19 Fear in Five European Countries before Mass Vaccination and Key Predictors among Nurses and Nursing Students. Vaccines 2022, 10, 98. https:/ / doi.org/10.3390/vaccines10010098

Academic Editor:

Alessandra Casuccio

Received: 26 November 2021

Accepted: 5 January 2022

Published: 10 January 2022

Publisher's Note: MDPI stays neutral with regard to jurisdictional claims in published maps and institutional affiliations.

Copyright: (C) 2022 by the authors. Licensee MDPI, Basel, Switzerland. This article is an open access article distributed under the terms and conditions of the Creative Commons Attribution (CC BY) license (https:// creativecommons.org/licenses/by/ $4.0 /)$.
1 Department of Nursing, School of Health Sciences, Hellenic Mediterranean University, 71410 Crete, Greece; apatelarou@hmu.gr

2 Clinical Epidemiology Laboratory, Department of Nursing, National and Kapodistrian University of Athens, 15772 Athens, Greece; pegalan@nurs.uoa.gr (P.G.); athkal@nurs.uoa.gr (A.K.)

3 Clinic of Social and Family Medicine, School of Medicine, University of Crete, 70013 Crete, Greece; mechili@univlora.edu.al

4 Department of Healthcare, Faculty of Health, University of Vlora, 9401 Vlora, Albania; ekicaj@yahoo.it (E.K.); jorgjia.bucaj@univlora.edu.al (J.B.); majlinda.zahaj@univlora.edu.al (M.Z.)

5 Department of Psychology and Social Sciences, Frederick University, Nicosia 3080, Cyprus; pre.aa@frederick.ac.cy

6 Department of Nursing, Frederick University, Nicosia 3080, Cyprus; hsc.arg@frederick.ac.cy (A.A.); hsc.ae@frederick.ac.cy (E.A.)

7 IMCU Group, Faculty of Physiotherapy and Nursing, University of Castilla-La Mancha, 45004 Toledo, Spain; JuanManuel.Carmona@uclm.es (J.M.C.-T.); AnaIsabel.cobo@uclm.es (A.I.C.-C.)

8 Department of Nursing and Midwifery, Faculty of Medicine, University of Ostrava, 70103 Ostrava, Czech Republic; jakub.dolezel@osu.cz (J.D.); darja.jarosova@osu.cz (D.J.)

9 Department of Surgery, Medicine, Dentistry and Morphological Sciences, University of Modena and Reggio Emilia, 41121 Reggio Emilia, Italy; sfinotto@unimore.it (S.F.); daniela.mecugni@unimore.it (D.M.)

10 Degree Course in Nursing, Azienda USL-IRCCS di Reggio Emilia, 41121 Reggio Emilia, Italy

11 Faculty of Nursing, AAB College, P.O. Box 10000 Pristina, Kosovo; velide.pulomemoj@universitetiaab.com (V.P.); idriz.sopjani@universitetiaab.com (I.S.)

12 Research Centre of Public Health, Faculty of Health, University of Vlora, 9401 Vlora, Albania; kmalaj3@yahoo.com

* Correspondence: epatelarou@hmu.gr

\begin{abstract}
Background: Levels of fear have increased since the COVID-19 pandemic outbreak. The absence of a safe and effective vaccine for mass-vaccination deteriorates this situation, which has a significant impact on mental health. This study aimed to assess the feelings of fear among nurses and nursing students in five European countries. Methods: A multicenter cross-sectional study was conducted in five European countries (Greece, Albania, Cyprus, Spain, and Kosovo) before the start of mass vaccination in Europe. Data collection was conducted in December 2020-January 2021 using an online questionnaire for nursing students and professional nurses. Fear of COVID-19 Scale (FCV-19S) was used for measuring levels of fear. IBM SPSS version 21.0 was used for statistical analysis. Results: The study population included 1135 nurses and 1920 nursing students from Kosovo $(n=1085)$, Spain $(n=663)$, Greece $(n=534)$, Albania $(n=529)$, and Cyprus $(n=244)$. According to multivariable analysis, females $(\mathrm{OR}=2.53,95 \% \mathrm{CI}=1.89-3.15)$, married $(\mathrm{OR}=0.86,95 \% \mathrm{CI}=0.24-1.48)$, nurses $(\mathrm{OR}=0.87,95 \% \mathrm{CI}=0.28-1.45)$ and those with a chronic disease $(\mathrm{OR}=0.86,95 \% \mathrm{CI}=0.11-1.62)$ were more fearful of COVID-19. Conclusions: It is important to decrease fear in the population of nurses who are at the frontlines of the pandemic. The provision of appropriate education and training activities for nurses and students to manage their stress levels is of high importance. Future studies should focus on levels of fear after the administration of several safe and effective vaccines worldwide.
\end{abstract}




\section{Introduction}

Since the outbreak of the COVID-19 pandemic, there has been an increase in the level of fear of the virus in the general population and, consequently, an increase in scientific interest in studying this fear and its consequences on mental health. Ahorsu et al. [1] constructed a scale for measuring the public's fear of COVID-19, and similar efforts have also been made in several studies using weighing scales to measure the fear of COVID-19 [2-8]. Research to date focuses on specific population groups in the United States [9], India [10], Pakistan [11], the Philippines [12], and Spain [4], but there is a significant research gap in studies involving southern Mediterranean countries, as well as multifactorial studies or other research efforts involving a large population sample in several countries simultaneously. What is certain, however, is the very existence of the population's fear of the SARS-CoV-2 virus $[10,13,14]$. At the same time, insufficient data have been recorded for the population of professional nurses and nursing students, a population group that has come into extensive direct contact with COVID-19-positive cases. The first available research results have shown that the emergence of COVID-19 has significantly impacted the mental health and well-being of nurses [15-17], but even more relevant studies are needed so that the scientific community can come to safe conclusions. In the last two years, there has been significant research interest in the study of psychological readiness as well as in the psychological consequences experienced by health professionals, especially medical and nursing staff [18-21]. However, many health professionals with chronic conditions seem to suffer from higher levels of depression, stress, and anxiety [22]. The psychological pressure caused by this pandemic has been shown to lead to an increase in vaccinations for medical and nursing staff, as well as for nursing students $[23,24]$. The level of hesitation in terms of vaccinations has been researched, related to influenza vaccination, showing a positive correlation $[25,26]$, as well as an increased interest from researchers in the existence of such a correlation.

In fact, this discussion has highlighted issues of trust in the safety of vaccines for the protection of nurses and nursing students, as well as issues of trust in specialists and the governments that promote them [27-29]. There is still a lack of studies to compare the aforementioned trust and fear between professional nurses and nursing students; however, at this level, researchers have begun to work on this correlation [18] but have not reached generalized results.

From the above it becomes clear that the coronavirus has caused fear and unpleasant feelings in both the general population and among health professionals. To date, research on the experience of nurses and nursing students who first came across the coronavirus, from the entire social context in terms of feelings of fear, is quite limited, which aroused the interest of our research team and was the incentive for this study. This study aimed to assess feelings of fear among nurses and nursing students in five European countries.

\section{Materials and Methods}

A multicenter cross-sectional study was conducted in five countries (Greece, Albania, Cyprus, Spain, and Kosovo) during the so-called second wave of the COVID-19 pandemic. In brief, in all countries data was collected December 2020-January 2021. Our sample consisted of undergraduate nursing students who were attending online or face-to-face classes organized by 7 universities in participating countries, and professional nurses were also contacted via email (sent by relevant nurses' associations and councils), newsletters, and social networks. Students and nurses were invited to participate in the study through a web survey, which included general information regarding the purpose and the process of the study. Before completing the questionnaire, participants gave their written consent to participate in the study. The questionnaire was anonymous and no personal data were 
recorded. Participation in the study was voluntary and individuals could withdraw at any moment. The questionnaire comprised 29 items, with a mean duration of 6-8 min to complete. Questions were included about demographic characteristics, perceived knowledge and beliefs regarding coronavirus and the COVID-19 vaccine, trust towards the experts, doctors, and government, and factors influencing the students' intention to vaccinate against the COVID-19 virus. The second part of the instrument included the Fear of COVID-19 Scale (FCV-19S) which was used to measure the fear of the coronavirus [1]. Cronbach's alpha coefficient for the fear of COVID-19 scale was 0.87 and thus internal consistency was great. Study details and questionnaire development and validation processes are provided elsewhere [24,30].

Continuous variables are presented as mean and standard deviation, while categorical variables are presented as numbers and percentages. We used mortality from COVID-19 (deaths per million population) to categorize the five countries in three categories: high mortality (>800 deaths per million population) [31], moderate mortality (400-800 deaths per million population), and low mortality ( $<400$ deaths per million population). The low mortality group included Cyprus, the moderate mortality group included Greece, Kosovo, and Albania, and the high mortality group included Spain. Fear of COVID-19 was the dependent variable, while demographic data and participants' answers regarding the COVID-19 pandemic and vaccination were the independent variables. Differences between nurses and nursing students were assessed with the chi-square test, chi-square trend test, and independent samples $t$-test. We created univariate and multivariable linear regression models. In the multivariable model, we included variables with a $p$-value $<0.20$ in the univariate analysis, applying the backward stepwise model. In the regression models, we merged answers in some variables for theoretical and statistical reasons. In particular, we merged the answers "very low" and "low", as well as the answers "high" and "very high", since the meanings were the same. Moreover, in the item "accept a safe and effective COVID-19 vaccine" we considered the answers "somewhat agree" and "completely agree" as "yes" and the other answers as "no" since we wanted to make explicit the intention of participants to accept a COVID-19 vaccine or not. We estimated unadjusted and adjusted beta coefficients with $95 \%$ confidence intervals (CI) and $p$-values. All tests of statistical significance were two-tailed, and $p$-values less than 0.05 were considered significant. We used Statistical Package for Social Sciences software (IBM Corp. Released 2012. IBM SPSS Statistics for Windows, Version 21.0. IBM, Armonk, NY, USA) to perform statistical analyses.

\section{Results}

\section{Results and Data Analysis}

Detailed demographic characteristics of the study population are presented in Table 1. The study population included 1135 nurses and 1920 nursing students; from Kosovo $(n=1085)$, Spain $(n=663)$, Greece $(n=534)$, Albania $(n=529)$, and Cyprus $(n=244)$. Nurses were older than nursing students (38.3 years vs. 21$)$, and chronic disease was more frequent among nurses (21.1\% vs. $5.8 \%)$.

Study population answers regarding the COVID-19 pandemic are shown in Table 2. Nurses had come into contact with a confirmed or suspected case of COVID-19 more often than nursing students $(81.5 \%$ vs. $49.6 \%, p<0.001)$. Significant percentages of nurses and nursing students had been infected with COVID-19 (19.2\% and 11.7\%, respectively, $p<0.001)$. COVID-19 infections were even higher among participants' family members/friends. In particular, $67.7 \%$ of nurses' family members/friends had been infected with COVID-19, while the respective percentage for nursing students was $60.1 \%$ $(p<0.001)$. Self-perceived knowledge about COVID-19 was high/very high for both groups (65.1\% for nurses and 60.2\% for nursing students) but low/very low regarding COVID-19 vaccines (44.1\% for nurses and $55.2 \%$ for nursing students). A significantly higher percentage of nurses was vaccinated for influenza in 2019 and 2020 (36.2\% vs. 4.5\%, $p<0.001)$. Trust in the government regarding information about COVID-19 was low (36.7\%), but trust 
in doctors and government experts was moderate to high $(72.2 \%$ and $63.1 \%$, respectively). Willingness to accept a safe and effective COVID-19 vaccine was higher among nurses $(p<0.001)$. In particular, $65.3 \%$ of nurses somewhat/completely agreed to accept a novel COVID-19 vaccine, while the respective percentage for nursing students was $43.7 \%$.

Table 1. Demographic characteristics of the study population.

\begin{tabular}{|c|c|c|c|c|c|}
\hline \multirow[t]{2}{*}{ Characteristics } & \multicolumn{2}{|c|}{ Nursing Students } & \multicolumn{2}{|c|}{ Nurses } & \multirow{2}{*}{$p$-Value } \\
\hline & $n$ & $\%$ & $n$ & $\%$ & \\
\hline Gender & & & & & $0.6^{\mathrm{a}}$ \\
\hline Male & 307 & 16.0 & 173 & 15.3 & \\
\hline Female & 1610 & 84.0 & 960 & 84.7 & \\
\hline $\begin{array}{l}\text { Age (years), mean, } \\
\text { standard deviation }\end{array}$ & 21.0 & 4.6 & 38.3 & 10.9 & $<0.001^{b}$ \\
\hline Country of origin & & & & & $<0.001^{a}$ \\
\hline Albania & 313 & 16.3 & 216 & 19.0 & \\
\hline Greece & 275 & 14.3 & 259 & 22.8 & \\
\hline Spain & 181 & 9.4 & 482 & 42.5 & \\
\hline Cyprus & 131 & 6.8 & 113 & 10.0 & \\
\hline Kosovo & 1020 & 53.1 & 65 & 5.7 & \\
\hline Marital status & & & & & $<0.001^{a}$ \\
\hline Single & 1735 & 91.1 & 445 & 39.3 & \\
\hline Married & 153 & 8.0 & 601 & 53.1 & \\
\hline Widowed & 2 & 0.1 & 8 & 0.7 & \\
\hline Divorced & 15 & 0.8 & 77 & 6.8 & \\
\hline Chronic disease & & & & & $<0.001^{a}$ \\
\hline Yes & 111 & 5.8 & 240 & 21.1 & \\
\hline No & 1806 & 94.2 & 895 & 78.9 & \\
\hline $\begin{array}{l}\text { Living with vulnerable groups } \\
\text { during the COVID-19 pandemic }\end{array}$ & & & & & $<0.001^{a}$ \\
\hline Yes & 785 & 40.9 & 384 & 33.8 & \\
\hline No & 1133 & 59.0 & 751 & 66.2 & \\
\hline
\end{tabular}

a chi-square test; ${ }^{\mathrm{b}}$ independent samples $t$-test.

Table 2. Study population answers regarding COVID-19.

\begin{tabular}{|c|c|c|c|c|c|}
\hline & \multicolumn{2}{|c|}{ Nursing Students } & \multicolumn{2}{|c|}{ Nurses } & \multirow{2}{*}{$p$-Value } \\
\hline & $n$ & $\%$ & $n$ & $\%$ & \\
\hline $\begin{array}{l}\text { Contact with a confirmed or a } \\
\text { suspected case of COVID-19 }\end{array}$ & & & & & $<0.001^{\mathrm{a}}$ \\
\hline Yes & 951 & 49.6 & 924 & 81.5 & \\
\hline No & 965 & 50.4 & 210 & 18.5 & \\
\hline Infected with COVID-19 & & & & & $<0.001^{\mathrm{a}}$ \\
\hline Yes & 225 & 11.7 & 218 & 19.2 & \\
\hline No & 1693 & 88.3 & 915 & 80.8 & \\
\hline $\begin{array}{l}\text { Family members/friends infected } \\
\text { with COVID-19 }\end{array}$ & & & & & $<0.001^{\mathrm{a}}$ \\
\hline Yes & 1150 & 60.1 & 766 & 67.7 & \\
\hline No & 764 & 39.9 & 366 & 32.3 & \\
\hline
\end{tabular}


Table 2. Cont.

\begin{tabular}{|c|c|c|c|c|c|}
\hline & \multicolumn{2}{|c|}{ Nursing Students } & \multicolumn{2}{|c|}{ Nurses } & \multirow{2}{*}{$p$-Value } \\
\hline & $n$ & $\%$ & $n$ & $\%$ & \\
\hline $\begin{array}{l}\text { Self-perceived likelihood of getting } \\
\text { infected with COVID-19 in the future }\end{array}$ & & & & & $<0.001^{b}$ \\
\hline Very low & 69 & 3.9 & 20 & 2.2 & \\
\hline Low & 410 & 22.9 & 110 & 12.0 & \\
\hline Moderate & 862 & 48.1 & 348 & 38.0 & \\
\hline High & 326 & 18.2 & 314 & 34.3 & \\
\hline Very high & 124 & 6.9 & 124 & 13.5 & \\
\hline $\begin{array}{l}\text { Self-perceived knowledge about } \\
\text { COVID-19 }\end{array}$ & & & & & $<0.001^{b}$ \\
\hline Very low & 16 & 0.8 & 2 & 0.2 & \\
\hline Low & 55 & 2.9 & 25 & 2.2 & \\
\hline Moderate & 692 & 36.1 & 369 & 32.6 & \\
\hline High & 918 & 47.8 & 552 & 48.8 & \\
\hline Very high & 238 & 12.4 & 184 & 16.3 & \\
\hline $\begin{array}{l}\text { Self-perceived knowledge about } \\
\text { COVID-19 vaccines }\end{array}$ & & & & & $<0.001^{b}$ \\
\hline Very low & 361 & 18.8 & 133 & 11.7 & \\
\hline Low & 699 & 36.4 & 367 & 32.4 & \\
\hline Moderate & 680 & 35.4 & 432 & 38.1 & \\
\hline High & 132 & 6.9 & 153 & 13.5 & \\
\hline Very high & 48 & 2.5 & 48 & 4.2 & \\
\hline $\begin{array}{l}\text { Influenza vaccination in } 2019 \\
\text { and } 2020\end{array}$ & & & & & $<0.001^{a}$ \\
\hline No & 1830 & 95.5 & 724 & 63.8 & \\
\hline Yes & 86 & 4.5 & 411 & 36.2 & \\
\hline Trust in government & & & & & $0.1^{\mathrm{a}}$ \\
\hline Yes & 680 & 35.6 & 436 & 38.6 & \\
\hline No & 1230 & 64.4 & 694 & 61.4 & \\
\hline $\begin{array}{l}\text { Trust in doctors regarding } \\
\text { information about COVID-19 }\end{array}$ & & & & & $0.1^{a}$ \\
\hline Yes & 1363 & 71.1 & 836 & 74.0 & \\
\hline No & 553 & 28.9 & 294 & 26.0 & \\
\hline $\begin{array}{l}\text { Trust in government experts } \\
\text { regarding information about } \\
\text { COVID-19 }\end{array}$ & & & & & $0.7^{\mathrm{a}}$ \\
\hline Yes & 1214 & 63.3 & 708 & 62.6 & \\
\hline No & 703 & 36.7 & 423 & 37.4 & \\
\hline $\begin{array}{l}\text { Accept a safe and effective } \\
\text { COVID-19 vaccine }\end{array}$ & & & & & $<0.001^{b}$ \\
\hline Completely disagree & 233 & 12.1 & 55 & 4.8 & \\
\hline Somewhat disagree & 205 & 10.7 & 43 & 3.8 & \\
\hline Neutral & 642 & 33.4 & 296 & 26.1 & \\
\hline Somewhat agree & 465 & 24.2 & 334 & 29.4 & \\
\hline Completely agree & 375 & 19.5 & 407 & 35.9 & \\
\hline
\end{tabular}

${ }^{\mathrm{a}}$ chi-square test; ${ }^{\mathrm{b}}$ chi-square trend test.

Nurses experienced more fear of COVID-19 than nursing students (mean score; 16.2 and 14.6, respectively, $p<0.001$ ); the mean total score was 15.2 (standard deviation; 5.9) with a range from 7 to 35 .

Results from univariate and multivariable linear regression analyses are shown in Table 3. According to multivariable linear regression model, females $(\mathrm{OR}=2.53,95 \% \mathrm{CI}=1.89-3.15)$ and married (OR $=0.86,95 \% \mathrm{CI}=0.24-1.48)$ experienced more fear of COVID-19. Levels of COVID-19 fear were higher among nurses $(\mathrm{OR}=0.87,95 \% \mathrm{CI}=0.28-1.45)$ and those 
with a chronic disease $(\mathrm{OR}=0.86,95 \% \mathrm{CI}=0.11-1.62)$. Participants living in countries with higher mortality from COVID-19 were more afraid of the disease (middle vs. low mortality group; $\mathrm{OR}=1.88,95 \% \mathrm{CI}=1.02-2.75$, high vs. low mortality group; $\mathrm{OR}=2.82$, $95 \% \mathrm{CI}=1.89-3.74)$.

Table 3. Univariate and multivariable linear regression analysis with fear against COVID-19 as the dependent variable.

\begin{tabular}{|c|c|c|c|c|}
\hline Variable & $\begin{array}{l}\text { Unadjusted Coefficient Beta } \\
\qquad(95 \% \mathrm{CI})\end{array}$ & $p$-Value & $\begin{array}{l}\text { Adjusted Coefficient Beta } \\
\qquad(95 \% \text { CI })\end{array}$ & $p$-Value \\
\hline Gender (females vs. males) & $2.82(2.24$ to 3.39$)$ & $<0.001$ & 2.53 (1.89 to 3.15$)$ & $<0.001$ \\
\hline Age & 0.07 (0.05 to 0.09$)$ & $<0.001$ & NS & \\
\hline Nurses vs. nursing students & 1.61 (1.18 to 2.05$)$ & $<0.001$ & $0.87(0.28$ to 1.45$)$ & 0.004 \\
\hline $\begin{array}{l}\text { Mortality group per million population } \\
\text { Low } \\
\text { Middle } \\
\text { High }\end{array}$ & $\begin{array}{c}1.00 \text { (reference) } \\
-0.60(-1.05 \text { to }-0.16) \\
1.41(0.94 \text { to } 1.88)\end{array}$ & $\begin{array}{c}0.007 \\
<0.001\end{array}$ & $\begin{array}{c}1.00 \text { (reference) } \\
1.88(1.02 \text { to } 2.75) \\
2.82(1.89 \text { to } 3.74) \\
\end{array}$ & $\begin{array}{l}<0.001 \\
<0.001\end{array}$ \\
\hline $\begin{array}{l}\text { Marital status (married vs. } \\
\text { single/widowed/divorced) }\end{array}$ & $1.71(1.22$ to 2.20$)$ & $<0.001$ & $0.86(0.24$ to 1.45$)$ & 0.007 \\
\hline Chronic disease (yes vs. no) & $1.73(1.06$ to 2.39$)$ & $<0.001$ & $0.86(0.11$ to 1.61$)$ & 0.024 \\
\hline $\begin{array}{l}\text { Living with vulnerable groups during } \\
\text { the COVID-19 pandemic (yes vs. no) }\end{array}$ & 0.007 (-0.005 to 0.018$)$ & 0.27 & NS & \\
\hline $\begin{array}{l}\text { Contact with a confirmed or a suspected } \\
\text { case of COVID-19 (yes vs. no) }\end{array}$ & $0.62(0.19$ to 1.06$)$ & 0.005 & NS & \\
\hline Infected with COVID-19 (yes vs. no) & $0.09(-0.51$ to 0.70$)$ & 0.75 & NS & \\
\hline $\begin{array}{l}\text { Family members/friends infected with } \\
\text { COVID-19 (yes vs. no) }\end{array}$ & $0.15(-0.29$ to 0.59$)$ & 0.50 & NS & \\
\hline $\begin{array}{l}\text { Self-perceived likelihood of getting } \\
\text { infected with COVID-19 in the future } \\
\text { Low/very low } \\
\text { Moderate } \\
\text { High/very high }\end{array}$ & $\begin{array}{l}1.00 \text { (reference) } \\
0.32(0.14 \text { to } 0.78) \\
0.71(0.23 \text { to } 1.19) \\
\end{array}$ & $\begin{array}{c}0.17 \\
0.004\end{array}$ & $\begin{array}{l}\text { NS } \\
\text { NS }\end{array}$ & \\
\hline $\begin{array}{l}\text { Self-perceived knowledge about } \\
\text { COVID-19 } \\
\text { Low/very low } \\
\text { Moderate } \\
\text { High/very high }\end{array}$ & $\begin{array}{c}1.00 \text { (reference) } \\
0.08(-0.36 \text { to } 0.52) \\
0.09(-0.35 \text { to } 0.53)\end{array}$ & $\begin{array}{c}0.718 \\
0.70\end{array}$ & $\begin{array}{l}\text { NS } \\
\text { NS }\end{array}$ & \\
\hline $\begin{array}{l}\text { Self-perceived knowledge about } \\
\text { COVID-19 vaccines } \\
\text { Low/very low } \\
\text { Moderate } \\
\text { High/very high }\end{array}$ & $\begin{array}{c}1.00 \text { (reference) } \\
-0.01(-0.45 \text { to } 0.43) \\
-0.14(-0.78 \text { to } 0.51)\end{array}$ & $\begin{array}{l}0.96 \\
0.68\end{array}$ & $\begin{array}{l}\text { NS } \\
\text { NS }\end{array}$ & \\
\hline $\begin{array}{l}\text { Influenza vaccination in } 2019 \text { and } 2020 \\
\text { (yes vs. no) }\end{array}$ & 0.87 (0.59 to 1.15$)$ & $<0.001$ & NS & \\
\hline Trust in government (yes vs. no) & $0.29(-0.16$ to 0.73$)$ & 0.203 & NS & \\
\hline $\begin{array}{l}\text { Trust in doctors regarding information } \\
\text { about COVID-19 (yes vs. no) }\end{array}$ & 0.58 (0.11 to 1.05$)$ & 0.017 & NS & \\
\hline $\begin{array}{l}\text { Trust in government experts regarding } \\
\text { information about COVID-19 (yes vs. no) }\end{array}$ & $0.12(-0.32$ to 0.56$)$ & 0.586 & NS & \\
\hline $\begin{array}{l}\text { Accept a safe and effective COVID-19 } \\
\text { vaccine (yes vs. no) }\end{array}$ & $0.88(0.46$ to 1.31$)$ & $<0.001$ & NS & \\
\hline
\end{tabular}

CI: confidence interval; NS: not selected by the backward elimination procedure in the multivariable linear regression analysis with a significance level set at 0.05 and the R2 for the final multivariable model was 5.7\%.

\section{Discussion}

This study aimed to assess factors that affect fear of COVID-19 among nurses and nursing students in five countries during the ongoing pandemic. Nurses experienced more fear than nursing students. 
Similar results to our study were reported by Huang et al. [18]; the authors reported higher levels of fear among nurses than nursing college students. In general, nurses have been on the frontline throughout the pandemic. Their working environment brings them in daily contact with COVID-19 patients, and exposes them more to the disease. Fear of being infected, the possible infection of family members, infected colleagues and friends, daily contact with COVID-19 patients who died from the disease, long working hours, and the unknowns of the disease are the most probable key reasons for these results. Additionally, being afraid of infecting relatives or friends increases the levels of fear and stress among nurses, as reported by Huang et al. [18]. A study in the Philippines reported high levels of fear due to COVID-19 among nurses [32], while a study in China among frontline nurses reported moderate and high levels of fear [33]. Another study found that nursing students exhibit less fear and sadness than frontline nurses [18]. Psychological distress during patient care and patient loss despite nurses' efforts to save them are other possible reasons for these results $[18,34]$. However, a lack of participation in COVID-19 training activities and job insecurity (working part-time) are other important factors, as mentioned in another study [32]. Level of health literacy is directly connected with COVID-19 fear [35]; however, this contrasts with the current study. Nurses in frontline positions have more knowledge and are probably more afraid because they know the severity of the disease, while nursing students are younger and probably overestimate their health status. Additionally, lack of medical equipment (especially during the first period of the pandemic) and fear of infection and possible isolation could also explain the higher levels of fear among nurses. However, further studies are needed to confirm this.

In the current study, we saw that women are more likely to present higher level of stress than men. High levels of anxiety are reported in studies among nursing students and frontline nurses [33,36]. Additionally, women have reported higher level of fear in comparison to men in different studies $[33,35,37]$. The female gender tends to relate more with anxiety and psychological distress [38]; to some extent, a Cuban study concluded that female gender is a key predictor of medium and high level of fear of COVID-19 [37]. The results of the present study could be due to the much higher number of women who participated in the study in comparison to men. However, similar results have been reported to general population studies suggesting that women are experiencing the COVID19 situation worse than men $[2,39,40]$. The prevalence of mood and anxiety disorders are usually higher in women than men [41]. These results more likely relate to biological, social, and psychosocial factors. Women's role in society is complex. They are involved in all aspects of life, participating in both housekeeping and the job market. These increased responsibilities activate stress mechanisms. In contrast, men are usually more indifferent to various aspects of life and experience different stressful situations more easily. However, female nurses reported a higher level of insomnia in a study in Wuhan than men [41]. Having sleep problems may also increase levels of fear.

Participants from countries with middle and high mortality rates due to COVID-19 reported higher levels of stress in this research. A study among nursing students reported higher levels of depression for Spanish students than Albanians and Greeks [42]. Spain death rates per 100,000 people for COVID-19 are much higher than Greece and Albania [31]. Those who follow the daily numbers of infection and death from COVID-19 experience more fear. Fear of infecting themselves and possible infection of their loved ones that could lead to serious problems and/or death could explain these results. The high volume of information received from traditional and non-traditional media could also impact these results. The ongoing "infodemic" during this period could be an additional factor, especially in the most affected countries.

The present study reports that marital status was also connected with levels of fear. Married participants reported higher fear levels than single/widowed/divorced participants. Hendrick and Hendrick reported that "love in the age of the Coronavirus is challenging" [43]. Most of the nurses participating in the current study are older and married in comparison to nursing students. Being afraid of getting infected and a possible 
transmission to their family members increase the levels of fear. Additionally, as nurses are also often the breadwinner for their families, possible financial hardships due to the COVID-19 situation could also be an explanatory factor. In contrast to the results of the current work, a study among primary medical staff in China reported that being married was a protective factor for development of psychological problems [26]. Support from the family environment is a possible factor for decreasing stress levels. Additionally, an Israeli study reported that martial satisfaction of women is linked with fear of COVID-19 [44]. This factor was not assessed in this study and future research is needed.

Participants with a chronic condition reported higher levels of stress in comparison to those without. Similar results are reported by the study of Mekonen et al. [22]; the authors concluded that levels of depression, stress, and anxiety are much higher for nurses with chronic conditions in comparison to those who do not. In a study of students, having a chronic medical condition was associated with high risk of stress [45]. Another study among frontline nurses in China reported that insomnia is related to existence of chronic conditions [46]. People with a chronic condition are more vulnerable to an infection with COVID-19. A possible infection in synergy with the existing health problem can worsen the situation. This combination probably stresses participants more and causes fear. However, a study conducted in Turkey reported that people without a chronic condition are more likely to have high anxiety levels in comparison to those with a chronic problem. Those authors believe that those with a medical condition are more aware of the disease and take better care of themselves [47]. Differences in education level of participants and years living with the chronic problem may be key reasons for these variations. Acceptance of a safe and effective COVID-19 vaccine was different between nursing students and nurses in the current study. In general, nurses were of higher age and at higher risk of serious illness and/or death in comparison to students who were younger. Additionally, working in hospitals puts nurses on the frontline, which also makes them vulnerable and this probably increased the acceptance rate. In a study among Italian university students, COVID-19 vaccine hesitance rates ranged between 22-29\% [48]. Additionally, authors reported that healthcare students had higher COVID-19 vaccine acceptance rates in comparison to other students [48]. In a study from the USA among medical students, around $25 \%$ of them were hesitant of having the COVID-19 vaccine [49]. The authors suggested the development of an educational curriculum for increasing knowledge and decreasing hesitancy levels [49]. A total of $88.3 \%$ of nursing students in a study in the Eastern USA believe that COVID-19 vaccines are safe and the acceptance rate was at 92\% [50].

\section{Strengths and Limitations}

To our best knowledge, this is among the first studies that aimed to assess factors that affect fear of COVID-19 among nurses and nursing students in five European countries. Large geographical coverage and an extensive number of participants are among the key strengths of the current research. Results also indicate key factors that could be addressed to decrease fear level of nurses and nursing students.

As with all studies, this work suffers from some limitations. The cross-sectional nature of the research makes it difficult to draw conclusions about causalities. Additionally, there was a lack of representativeness in each country during data collection. Participation of only nurses and nursing students makes generalization for other medical professions difficult. The online method of data collection is also a possible limitation for this study.

\section{Conclusions}

The current study focused on factors that affect levels of fear among nurses and nursing students before mass vaccination started in Europe. Key predictors of high levels of fear were female gender, marital status, existence of a chronic medical condition, and living in a country with high mortality rates due to COVID-19. Nurses are in the frontline of the pandemic while nursing students are the forthcoming health providers. It is of paramount significance to decrease the level of fear in these populations. Provision of appropriate 
education for students and training activities for nurses to manage their stress levels is of high importance. Researchers, policymakers, health authorities, and nurses' associations should work together to find appropriate and suitable coping strategies. Future research is needed to assess if differences exist between nurses and nursing students and other medical professions. Additionally, further studies should focus on the levels of fear after vaccination and assess if this process contributes to a better health status.

Author Contributions: Conceptualization, E.P., A.P., P.G. and E.A.M.; methodology, E.P., A.P., P.G. and E.A.M.; statistical analysis, P.G.; data collection, E.P., P.G., E.A.M., A.A. (Agathi Argyriadi), A.A. (AlexandrosArgyriadis), E.A., E.K., J.B., J.M.C.-T., A.I.C.-C., J.D., S.F., D.J., A.K., D.M., V.P., K.M., I.S., M.Z. and A.P.; writing—original draft preparation, E.P., A.P., P.G., A.A. (Agathi Argyriadi), E.A. and E.A.M.; writing-review and editing, all authors; all authors have contributed equally to this research. All authors have read and agreed to the published version of the manuscript.

Funding: There was no funding for this study.

Institutional Review Board Statement: The study was conducted according to the guidelines of the Declaration of Helsinki, and approved by the Institutional Review Board or Ethics Committee of all participants' countries.

Informed Consent Statement: Informed consent was obtained from all subjects involved in the study.

Data Availability Statement: Data can be found upon request from the corresponding author.

Conflicts of Interest: The authors declare no conflict of interest.

\section{References}

1. Ahorsu, D.K.; Lin, C.-Y.; Imani, V.; Saffari, M.; Griffiths, M.D.; Pakpour, A.H. The Fear of COVID-19 Scale: Development and Initial Validation. Int. J. Ment. Health Addict. 2020, 1-9. [CrossRef] [PubMed]

2. Bitan, D.T.; Grossman-Giron, A.; Bloch, Y.; Mayer, Y.; Shiffman, N.; Mendlovic, S. Fear of COVID-19 scale: Psychometric characteristics, reliability and validity in the Israeli population. Psychiatry Res. 2020, 289, 113100. [CrossRef]

3. Doshi, D.; Karunakar, P.; Sukhabogi, J.R.; Prasanna, J.S.; Mahajan, S.V. Assessing Coronavirus Fear in Indian Population Using the Fear of COVID-19 Scale. Int. J. Ment. Health Addict. 2020, 19, 2383-2391. [CrossRef]

4. Martínez-Lorca, M.; Martínez-Lorca, A.; Criado-Álvarez, J.J.; Armesilla, M.D.C. The fear of COVID-19 scale: Validation in spanish university students. Psychiatry Res. 2020, 293, 113350. [CrossRef]

5. Pakpour, A.H.; Griffiths, M.D.; Chang, K.-C.; Chen, Y.-P.; Kuo, Y.-J.; Lin, C.-Y. Assessing the fear of COVID-19 among different populations: A response to Ransing. Brain Behav. Immun. 2020, 89, 524-525. [CrossRef]

6. Pang, N.T.P.; Kamu, A.; Hambali, N.L.B.; Mun, H.C.; Kassim, M.A.; Mohamed, N.H.; Ayu, F.; Rahim, S.S.S.A.; Omar, A.; Jeffree, M.S. Malay Version of the Fear of COVID-19 Scale: Validity and Reliability. Int. J. Ment. Health Addict. 2020, 1-10. [CrossRef]

7. Perz, C.A.; Lang, B.A.; Harrington, R. Validation of the Fear of COVID-19 Scale in a US College Sample. Int. J. Ment. Health Addict. 2020, 1-11. [CrossRef] [PubMed]

8. Soraci, P.; Ferrari, A.; Abbiati, F.A.; Del Fante, E.; De Pace, R.; Urso, A.; Griffiths, M.D. Validation and psy-chometric evaluation of the Italian version of the Fear of COVID-19 Scale. Int. J. Ment. Health Addict. 2020, 1-10. [CrossRef]

9. Fitzpatrick, K.M.; Harris, C.; Drawve, G. Fear of COVID-19 and the mental health consequences in America. Psychol. Trauma Theory Res. Pract. Policy 2020, 12, 17-21. [CrossRef] [PubMed]

10. Goyal, K.; Chauhan, P.; Chhikara, K.; Gupta, P.; Singh, M.P. Fear of COVID 2019: First suicidal case in India! Asian J. Psychiatry 2020, 49, 101989. [CrossRef] [PubMed]

11. Khattak, S.R.; Saeed, I.; Rehman, S.U.; Fayaz, M. Impact of Fear of COVID-19 Pandemic on the Mental Health of Nurses in Pakistan. J. Loss Trauma 2020, 26, 421-435. [CrossRef]

12. De los Santos, J.A.A.; Labrague, L.J. The impact of fear of COVID-19 on job stress, and turnover intentions of frontline nurses in the community: A cross-sectional study in the Philippines. Traumatology 2021, 27, 52-59. [CrossRef]

13. Ornell, F.; Schuch, J.B.; Sordi, A.O.; Kessler, F.H.P. "Pandemic fear" and COVID-19: Mental health burden and strategies. Braz. J. Psychiatry 2020, 42, 232-235. [CrossRef] [PubMed]

14. Pakpour, A.H.; Griffiths, M.D. The fear of COVID-19 and its role in preventive behaviors. J. Concurr. Disord. 2020, 2, 58-63. [CrossRef]

15. Wujtewicz, M.; Dylczyk-Sommer, A.; Aszkiełowicz, A.; Zdanowski, S.; Piwowarczyk, S.; Owczuk, R. COVID-19-what should anaethesiologists and intensivists know about it? Anaesthesiol. Intensive Ther. 2020, 180, 934-943. [CrossRef] [PubMed]

16. Nemati, M.; Ebrahimi, B.; Nemati, F. Assessment of Iranian Nurses' Knowledge and Anxiety Toward COVID-19 During the Current Outbreak in Iran. Arch. Clin. Infect. Dis. 2020, 15. [CrossRef]

17. Mo, P.; Xing, Y.; Xiao, Y.U.; Deng, L.; Zhao, Q.; Wang, H.; Zhang, Y. Clinical characteristics of refractory COVID-19 pneumonia in Wuhan, China. Clin. Infect. Dis. 2020, 13, 9186-9224. 
18. Huang, L.; Lei, W.; Xu, F.; Liu, H.; Yu, L. Emotional responses and coping strategies in nurses and nursing stu-dents during COVID-19 outbreak: A comparative study. PLOS ONE 2020, 15, e0237303.

19. Liu, Z.; Han, B.; Jiang, R.; Huang, Y.; Ma, C.; Wen, J.; Ma, Y. Mental health status of doctors and nurses during COVID-19 epidemic in China. SSRN 2020, Preprint, 3551329. [CrossRef]

20. Shen, X.; Zou, X.; Zhong, X.; Yan, J.; Li, L. Psychological stress of ICU nurses in the time of COVID-19. Crit. Care 2020, 24, 200. [CrossRef]

21. Yifan, T.; Ying, L.; Chunhong, G.; Jing, S.; Rong, W.; Zhenyu, L.; Zejuan, G.; Peihung, L. Symptom Cluster of ICU Nurses Treating COVID-19 Pneumonia Patients in Wuhan, China. J. Pain Symptom Manag. 2020, 60, e48-e53. [CrossRef]

22. Aylie, N.S.; Mekonen, M.A.; Mekuria, R.M. The Psychological Impacts of COVID-19 Pandemic Among University Students in Bench-Sheko Zone, South-west Ethiopia: A Community-based Cross-sectional Study. Psychol. Res. Behav. Manag. 2020, 13, 813-821. [CrossRef] [PubMed]

23. Gagneux-Brunon, A.; Detoc, M.; Bruel, S.; Tardy, B.; Rozaire, O.; Frappe, P.; Botelho-Nevers, E. Intention to get vaccinations against COVID-19 in French healthcare workers during the first pandemic wave: A cross-sectional survey. J. Hosp. Infect. 2021, 108, 168-173. [CrossRef]

24. Patelarou, E.; Galanis, P.; Mechili, E.A.; Argyriadi, A.; Argyriadis, A.; Asimakopoulou, E.; Brokaj, S.; Bucaj, J.; Carmona-Torres, J.M.; Cobo-Cuenca, A.I.; et al. Factors influencing nursing students' intention to accept COVID-19 vaccination: A pooled analysis of seven European countries. Nurse Educ. Today 2021, 104, 105010. [CrossRef] [PubMed]

25. Kałucka, S.; Dziankowska-Zaborszczyk, E.; Grzegorczyk-Karolak, I.; Głowacka, A. A Comparison of the Attitudes to Influenza Vaccination Held by Nursing, Midwifery, Pharmacy, and Public Health Students and Their Knowledge of Viral Infections. Vaccines 2020, 8, 516. [CrossRef]

26. Wang, K.; Wong, E.L.Y.; Ho, K.F.; Cheung, A.W.L.; Chan, E.Y.Y.; Yeoh, E.K.; Wong, S.Y.S. Intention of nurses to accept Coronavirus disease 2019 vaccination and change of intention to accept seasonal influenza vac-cination during the Coronavirus disease 2019 pandemic: A cross-sectional survey. Vaccine 2020, 38, 7049-7056. [CrossRef]

27. Balog-Way, D.H.P.; McComas, K.A. COVID-19: Reflections on trust, tradeoffs, and preparedness. J. Risk Res. 2020, 23, 838-848 [CrossRef]

28. Banai, I.P.; Banai, B.; Mikloušić, I. Beliefs in COVID-19 conspiracy theories predict lower level of compliance with the preventive measures both directly and indirectly by lowering trust in government medical officials. Curr. Psychol. 2021, 1-11. [CrossRef]

29. Mansoor, M. Citizens' trust in government as a function of good governance and government agency's provision of quality information on social media during COVID-19. Gov. Inf. Q. 2021, 38, 101597. [CrossRef] [PubMed]

30. Patelarou, A.; Saliaj, A.; Galanis, P.; Pulomenaj, V.; Prifti, V.; Sopjani, I.; Patelarou, E. Predictors of nurses' intention to accept COVID-19 vaccination: A cross-sectional study in five European countries. J. Clin. Nurs. 2021. [CrossRef]

31. John Hopkins University. Coronavirus Resource Center. 2020. Available online: https://coronavirus.jhu.edu/map.html (accessed on 25 August 2021).

32. Labrague, L.J.; de Los Santos, J.A.A. Fear of COVID-19, psychological distress, work satisfaction and turnover intention among frontline nurses. J. Nurs. Manag. 2021, 29, 395-403. [CrossRef]

33. Hu, D.; Kong, Y.; Li, W.; Han, Q.; Zhang, X.; Zhu, L.X.; Wan, S.W.; Liu, Z.; Shen, Q.; Yang, J.; et al. Frontline nurses' burnout, anxiety, depression, and fear statuses and their associated factors during the COVID-19 outbreak in Wuhan, China: A large-scale cross-sectional study. EClinicalMedicine 2020, 24, 100424. [CrossRef]

34. Galehdar, N.; Kamran, A.; Toulabi, T.; Heydari, H. Exploring nurses' experiences of psychological distress during care of patients with COVID-19: A qualitative study. BMC Psychiatry 2020, 20, 489. [CrossRef]

35. Nguyen, H.T.; Do, B.N.; Pham, K.M.; Kim, G.B.; Dam, H.T.B.; Nguyen, T.T.; Nguyen, T.T.P.; Nguyen, Y.H.; Sørensen, K.; Pleasant, A.; et al. Fear of COVID-19 Scale-Associations of Its Scores with Health Literacy and Health-Related Behaviors among Medical Students. Int. J. Environ. Res. Public Health 2020, 17, 4164. [CrossRef]

36. Majrashi, A.; Khalil, A.; Nagshabandi, E.A.; Majrashi, A. Stressors and Coping Strategies among Nursing Stu-dents during the COVID-19 Pandemic: Scoping Review. Nurs. Rep. 2021, 11, 42. [CrossRef] [PubMed]

37. Broche-Pérez, Y.; Fernández-Fleites, Z.; Jiménez-Puig, E.; Fernández-Castillo, E.; Rodríguez-Martin, B.C. Gender and fear of COVID-19 in a Cuban population sample. Int. J. Ment. Health Addict. 2020, 1-9. [CrossRef] [PubMed]

38. Casagrande, M.; Favieri, F.; Tambelli, R.; Forte, G. The enemy who sealed the world: Effects quarantine due to the COVID-19 on sleep quality, anxiety, and psychological distress in the Italian population. Sleep Med. 2020, 75, 12-20. [CrossRef] [PubMed]

39. Rossi, R.; Socci, V.; Talevi, D.; Mensi, S.; Niolu, C.; Pacitti, F.; Di Lorenzo, G. COVID-19 pandemic and lock-down measures impact on mental health among the general population in Italy. Front. Psychiatry 2020, 11, 790. [CrossRef] [PubMed]

40. Mechili, E.A.; Saliaj, A.; Kamberi, F.; Girvalaki, C.; Peto, E.; Patelarou, A.E.; Bucaj, J.; Patelarou, E. Is the mental health of young students and their family members affected during the quarantine period? Evidence from the COVID-19 pandemic in Albania. $J$. Psychiatr. Ment. Health Nurs. 2021, 28, 317-325. [CrossRef]

41. Kiely, K.M.; Brady, B.; Byles, J. Gender, mental health and ageing. Maturitas 2019, 129, 76-84. [CrossRef]

42. Patelarou, A.; Mechili, E.A.; Galanis, P.; Zografakis-Sfakianakis, M.; Konstantinidis, T.; Saliaj, A.; Bucaj, J.; Alushi, E.; CarmonaTorres, J.M.; Cobo-Cuenca, A.I.; et al. Nursing students, mental health status during COVID-19 quarantine: Evidence from three European countries. J. Ment. Health 2021, 30, 164-169. [CrossRef]

43. Hendrick, S.S.; Hendrick, C. Romantic Love in the Age of COVID-19. J. Loss Trauma 2020, 25, 540-543. [CrossRef] 
44. Reizer, A.; Koslowsky, M.; Geffen, L. Living in fear: The relationship between fear of COVID-19, distress, health, and marital satisfaction among Israeli women. Health Care Women Int. 2020, 41, 1273-1293. [CrossRef]

45. Kassir, G.; El Hayek, S.; Zalzale, H.; Orsolini, L.; Bizri, M. Psychological distress experienced by self-quarantined undergraduate university students in Lebanon during the COVID-19 outbreak. Int. J. Psychiatry Clin. Pract. 2021, 25, 172-179. [CrossRef] [PubMed]

46. Zhan, Y.; Liu, Y.; Liu, H.; Li, M.; Shen, Y.; Gui, L.; Zhang, J.; Luo, Z.; Tao, X.; Yu, J. Factors associated with insomnia among Chinese frontline nurses Fighting against COVID-19 in Wuhan: A cross-sectional survey. J. Nurs. Manag. 2020, 28, 1525-1535. [CrossRef]

47. Gül, Ş.; Kılıç, S.T. Determining anxiety levels and related factors in operating room nurses during the COVID-19 pandemic: A descriptive study. J. Nurs. Manag. 2021, 29, 1934-1945. [CrossRef] [PubMed]

48. Baccolini, V.; Renzi, E.; Isonne, C.; Migliara, G.; Massimi, A.; De Vito, C.; Marzuillo, C.; Villari, P. COVID-19 Vaccine Hesitancy among Italian University Students: A Cross-Sectional Survey during the First Months of the Vaccination Campaign. Vaccines 2021, 9, 1292. [CrossRef]

49. Lucia, V.C.; Kelekar, A.; Afonso, N.M. COVID-19 vaccine hesitancy among medical students. J. Public Health 2020, 43, 445-449. [CrossRef] [PubMed]

50. Morris, J.L.; Baniak, L.; Luyster, F.; Dunbar-Jacob, J. COVID-19 Vaccine Confidence and Hesitancy in Nursing Students and Faculty at a Large Academic Medical Center. Nurs. Outlook 2021. [CrossRef] [PubMed] 